\title{
Prevalence of anti-beta-2 microglobulin autoantibodies in sera of rheumatoid arthritis patients with extra-articular manifestations
}

\author{
ANDRÁS FALUS, KATHERINE MERÉTEY, AND SÁNDOR BOZSÓKY \\ From the National Institute of Rheumatology and Physiotherapy, Hungary
}

SUMMARY The frequency and concentration of specific factors binding $\beta_{2}$ microglobulin were investigated in sera and synovial fluids of patients and in sera of normal controls. High anti- $\beta_{2} \mathrm{~m}$ activity was detected in the sera of adult RA patients, particularly in those of with extra-articular disease. Similarly, anti- $\beta_{2} \mathrm{~m}$ was present in the synovial fluids of RA but not of osteoarthrosis patients. Both the binding of anti- $\beta_{2} \mathrm{~m}$ activity to the Sepharose staphylococcal protein $A$ and its elution position in the second 'IgG' peak after Sephadex G-200 gel filtration suggest the antibody nature of the activity. The possibility of differences not only in titre but also in the specificity of heterologous and homologous anti- $\beta_{2} \mathrm{~m}$ antibodies are discussed.

Soluble beta- 2 microglobulin $\left(\beta_{2} \mathrm{~m}\right)$, a shed membrane protein subunit of human HLA antigens, can be found in relatively low concentration in biological fluids of healthy persons. ${ }^{1}$ An increased serum $\beta_{2} \mathrm{~m}$ level has been detected in malignant disease $^{2}$ and in infectious diseases. ${ }^{3}$ High $\beta_{2} \mathrm{~m}$ serum concentration is also characteristic of systemic lupus erythematosus (SLE) patients even with normal renal functions, ${ }^{4}$ the joint effusions of rheumatoid arthritis (RA) patients, ${ }^{5}$ and the saliva of patients with Sjögren's disease. ${ }^{6}$

Furthermore serum autoantibodies specific for $\beta_{2} \mathrm{~m}$ have been observed in SLE patients, ${ }^{7}$ representing a considerable part of the lymphocytotoxic human antibodies reactive against surface antigens. ${ }^{8}$

We previously reported our preliminary observations on the appearance of specific autoantibodies for $\beta_{2} \mathrm{~m}$ (partly coisolated with rheumatoid factors) in sera and synovial fluids (SF) of RA patients. ${ }^{9}$ Moreover, IgG complexes containing $\beta_{2} \mathrm{~m}$ from some sera and SFs of SLE and RA patients were detected and analysed. 1011

We report here that anti- $\beta_{2} \mathrm{~m}$ autoantibodies, reactive with staphylococcal protein A Sepharose (SPrA), can be frequently detected in sera of RA patients and especially in those with extra-articular symptoms.

Accepted for publication 1 August 1980

Correspondence to Dr A. Falus, Budapest 114, РOB 54, H-1525, Hungary.

\section{Materials and methods}

Blood was obtained from 104 patients with 'definite' or 'classical' RA according to American Rheumatism Association criteria. This group of patients consisted of 70 females and 34 males; the median age was 47 years, with a range from 32 to 71 years. Thirty-five of the RA patients showed 1 or more extra-articular signs of the disease, that is, subcutaneous nodules, vasculitic lesions of the skin, pleuropulmonary complications, episcleritis, or keratoconjunctivitis sicca. Blood samples of 30 patients with juvenile rheumatoid arthritis (JRA) were also investigated (median age 14 years, range from 5 to 35 years). Eight JRA patients could be classified as having a systemic onset of the disease whose symptoms were mainly fever, rash, iritis, and myocardial involvement. Synovial fluids were obtained from 26 RA patients and from 24 patients with osteoarthrosis (OA). The control group included 39 healthy females and 28 males ranging from 15 to 70 years of age.

Antihuman $\beta_{2} m$ rabbit antibody. Monospecific rabbit antibodies against human $\beta_{2}$ m was raised and kindly gifted by Dr P. A. Peterson (Uppsala) ${ }^{\mathbf{1 2}}$ and compared with monospecific rabbit antihuman $\beta_{2} \mathrm{~m}$ purchased from Dako Immunoglobulin Ltd.

$\beta_{2} m$ binding assay by Farr's radioimmune technique. $0.6 \mathrm{ng}$ purified $\beta_{2} \mathrm{~m}$ labelled with ${ }^{125} \mathrm{I}$ (tracer 
in Phadebas- $\beta_{2}$ microtest, Pharmacia, Uppsala) of specific activity: $93 \mu \mathrm{Ci} / \mu \mathrm{g}$ in $50 \mu \mathrm{l}$ of $0.1 \mathrm{M}$ borate buffer, $\mathrm{pH} 8 \cdot 2$, was mixed in polystyrene tubes with $50 \mu \mathrm{l}$ sample and $100 \mu \mathrm{l}$ of borate buffer supplemented with $1 \%$ Tween 20 and $1 \%$ bovine serum albumin. After $1 \mathrm{~h}$ incubation at $37^{\circ} \mathrm{C}$ and $16 \mathrm{~h}$ at $4^{\circ} \mathrm{C}, 200 \mu \mathrm{l}$ of saturated ammonium sulphate was added to each tube. After $20 \mathrm{~min}$ at room temperature tubes were centrifuged at $1500 \mathrm{~g}$ for $10 \mathrm{~min}$ and $200 \mu \mathrm{l}$ of the supernatant was removed. Total radioactivity (T) of the $0.6 \mathrm{ng} \beta_{2} \mathrm{~m}^{-125} \mathrm{I}$ added to the tubes and of the supernatant (S) was measured. Bound activity was calculated according to the formula: binding $\%=\frac{T-2 S}{T} \times 100$. Background values after adding buffer alone were subtracted from the test values. For synovial fluids from RA patients effusions from $\mathrm{OA}$ patients served as controls.

As a standard curve for the Farr's radioimmune assay $0.6 \mathrm{ng}$ labelled $\beta_{2} \mathrm{~m}$ in $50 \mu \mathrm{l}$ buffer was mixed with $150 \mu$ l dilutions of both batches of heterologous antihuman $\beta_{2}$ m (Fig. 1).

Staphylococcal protein A immunosorbent assay for detection of anti- $\beta_{2} m$ autoantibodies. $50 \mu \mathrm{l}$ of the samples were diluted with $100 \mu \mathrm{l}$ of $0.05 \mathrm{M}$ Tris$\mathrm{HCl}$ buffer, $\mathrm{pH} 7 \cdot 8$, supplemented with $0 \cdot 1 \mathrm{M}$ $\mathrm{NaCl}$ and incubated for 1 hour at room temperature with a Sepharose Protein A suspension (Pharmcia) of a concentration of $3 \times 10^{4}$ particles $/ \mathrm{ml}$. The

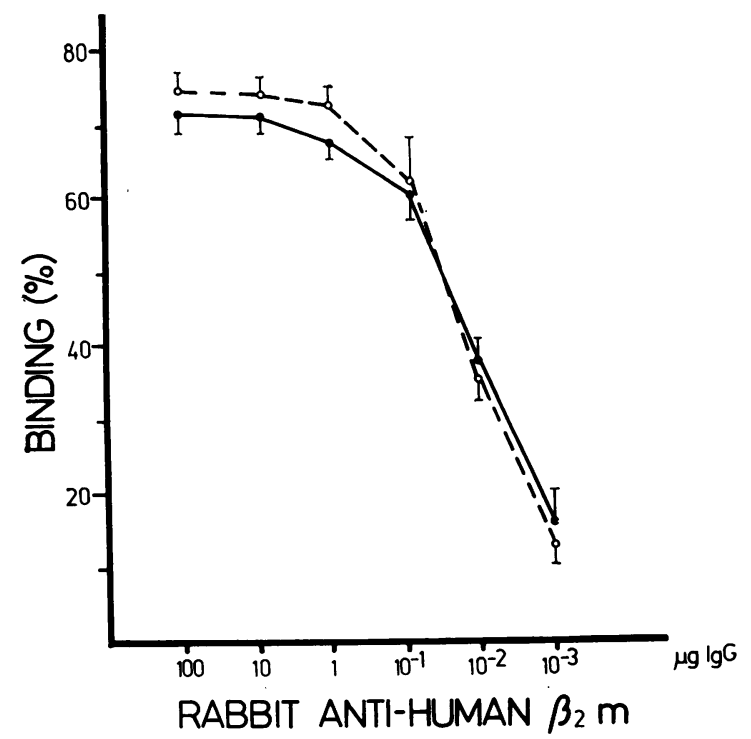

Fig. 1 Binding of beta-2-microglobulin by rabbit IgG specific for 0.001-100 $\mu \mathrm{g}$ human $\beta_{2} m$ from individual rabbit antiserum - and Dako anti- $\beta_{2} m---$. Mean $\pm S E M$ is indicated (4 experiments). suspensions were washed 3 times with Tris- $\mathrm{HCl}-$ $\mathrm{NaCl}$ buffer. $0.25 \mathrm{ng} \beta_{2} \mathrm{~m}^{-125} \mathrm{I}$ was added in $20 \mu \mathrm{l}$ buffer to each tube. After intensive shaking at room temperature for $2 \mathrm{~h}$ the suspensions were again washed 3 times in excess buffer and radioactivity absorbed to Sepharose protein A was measured. Background values were subtracted and the results were expressed as a percentage of total radioactivity added to the tubes.

Determination of immune complex (IC) concentrations by polyethylene glycol (PEG) precipitation. A modification ${ }^{13}$ of the method of Creighton et al. ${ }^{14}$ was used. Fresh samples were diluted 1:50 with 3\% PEG 6000 (Merck, Darmstadt, Germany) in $0.1 \mathrm{M}$ borate buffer and incubated for $16 \mathrm{~h}$ at $4^{\circ} \mathrm{C}$. After centrifugation at $3000 \mathrm{~g}$ for $20 \mathrm{~min}$, the precipitates were washed twice in $3 \%$ PEG and resuspended to the original sample volume in phosphate buffered saline at $\mathrm{pH} 7 \cdot 4$. The protein content of the IC-enriched fractions was determined by the method of Lowry et al..$^{15}$ A standard curve using dilutions of human IgG was plotted.

Determination of rheumatoid factor $(R F)$ titre. RF was measured by differential agglutination of sheep red blood cells sensitised with specific rabbit IgG and by latex agglutination tests. ${ }^{16}$

Gel filtration on Sephadex G-200. 0.6 ml samples of 5 sera and 3 SFs were fractionated on a Sephadex G-200 column measuring $1.5 \times 80 \mathrm{~cm}$, equilibrated with $0 \cdot 1 \mathrm{M}$ borate buffer at $\mathrm{pH} 8 \cdot 2$, and eluted at $10 \mathrm{ml} / \mathrm{h}$ with the same buffer. The fractions of the 3 major peaks were collected, pooled, concentrated to the original volume by PEG 20.000 , and dialysed against borate buffer. $\beta_{2} \mathrm{~m}$ binding activity of the fractions was determined as described above.

\section{Results}

The results are summarised in Fig. 2. It can be seen that in comparison with the healthy controls significantly higher binding activity was found in some sera of RA patients. In RA patients with extraarticular symptoms the mean of the binding values was especially high $(33 \cdot 71 \pm 1 \cdot 5)$, compared with the patients without extra-articular manifestations $(t=4 \cdot 58, \mathrm{P}<0 \cdot 0001)$.

A binding percentage exceeding the mean binding percentage of controls by 2 standard deviations was seen in 10 patients with RA, in 9 of whom extraarticular disease was present.

There was no significant difference between $\beta_{2}$ mbinding values of JRA patients and controls even in cases with systemic onset of the disease. 


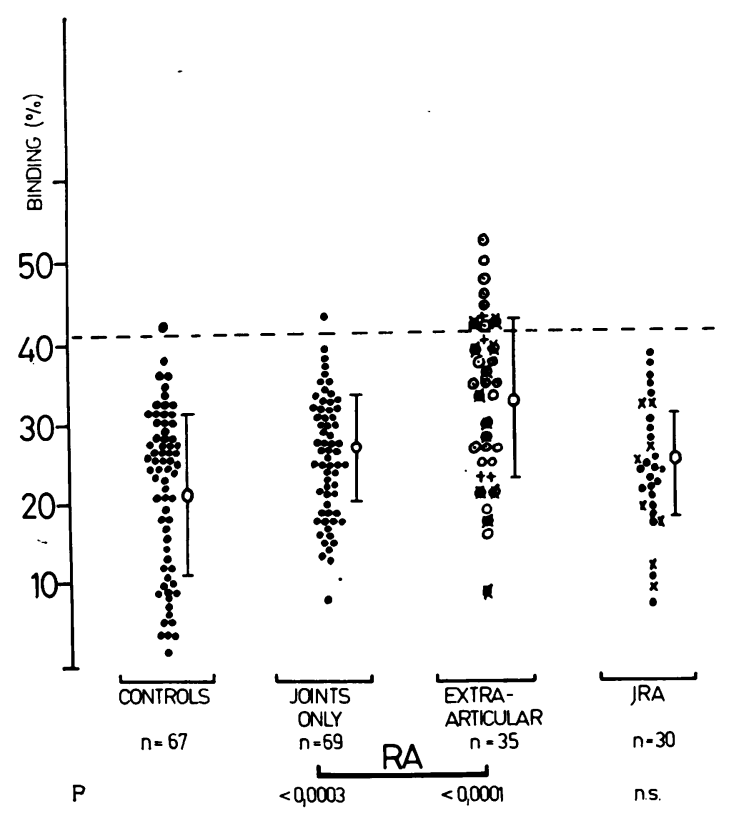

A significantly higher level of $\beta_{2} \mathrm{~m}$-specific binding factor was found in SFs from RA patients compared with those of $\mathrm{OA}$ patients. Higher $\beta_{2} \mathrm{~m}$ binding activity was not found in SFs from 4 RA patients with extra-articular complications compared with joint disease alone (data not shown).

Relatively high $\beta_{2} \mathrm{~m}$-binding activities were seen mainly in RA patients with pleuropulmonary lesions and nodules. Less striking increases were detected among patients with keratoconjunctivitis sicca syndrome.

Rheumatoid factor titres and immune complexes were also investigated in the sera of RA patients. $\beta_{2} \mathrm{~m}$ binding was not significantly related to RF positivity or with immune complexes (Table 1).

To elucidate the immunochemical nature of the $\beta_{2} \mathrm{~m}$-binding activity precipitable by $50 \%$ saturated

Table $1 \quad \beta_{2}$ microglobulin binding factors in sera of $R A$ patients with high and low RF titres and IC levels

\begin{tabular}{clll}
\hline & $n$ & $\begin{array}{l}\beta_{2} \text { m binding } \\
\text { percentages (mean } \pm S E M)\end{array}$ & $P$ \\
\hline Rheumatoid factor $^{1}$ & & & \\
$1: 16-1: 64$ & 27 & $26.46 \pm 0.79$ & NS \\
$1: 128-1: 4096$ & 29 & $27.30 \pm 1.08$ & \\
2PEG precipitation & & $24.99 \pm 0.66$ & NS \\
$\leqslant 200 \mu \mathrm{g} / \mathrm{ml}^{3}$ & 24 & $27.72 \pm 1.65$ & \\
$>200 \mu \mathrm{g} / \mathrm{ml}^{3}$ & 27 & 27.65 & \\
\hline
\end{tabular}

1Waaler-Rose indirect agglutination. All patients had positive latex agglutination in their sera.

$23 \%$ PEG 6000 precipitation test (see Materials and Methods).

3Limit of positivity in PEG assay (higher than mean of IC level in sera of 80 heal thy blood donors increased by two SD).
Fig. 2 Binding percentages for $\beta_{2} m$ of sera and synovial fluids $(S F)$ from normal controls, rheumatoid arthritis $(R A)$ patients, and juvenile rheumatoid arthritis (JRA) patients. Extra-articular manifestations: $\odot=$ subcutaneous nodules, $\oplus=$ pleuropulmonary signs, $+=$ vasculitic skin lesions, $\mathrm{O}=$ keratoconjunctivitis sicca.

- The symbol $\times$ represents values of JRA patients with systemic onset of the disease. Means $\pm S D$ are indicated in all groups. The dotted line shows 2 SD above the mean control level. $P$ values (Student's $\mathrm{t}$ test) are calculated by comparing binding percentages of sera from patients with $R A$ or JRA and those of normal controls. $S F$ from $R A$ patients are compared with effusions from OA patients.

Table 2 Reaction of labelled $\beta_{2}$ microglobulin on staphylococcal protein A immunosorbent precoated with serum dilutions from samples revealing high or low $\beta_{2} m$ binding activities

\begin{tabular}{lllll}
\hline $\begin{array}{l}\beta_{2} m \text { binding percentages } \\
\text { range }\end{array}$ & $n$ & $\begin{array}{l}\text { Percent binding of } \\
\beta_{2} m-125 I \text { to Spr } A^{1}\end{array}$ & Positivity $^{2}$ & $P^{3}$ \\
\hline $7 \cdot 35-10.5$ & 11 & $0.51 \pm 0.05$ & $2 / 11$ & \\
$27 \cdot 51-48.72$ & 13 & $5 \cdot 70 \pm 0.17$ & $12 / 13$ & $<0.0003$ \\
\hline
\end{tabular}

1 For details see Materials and Methods. Mean \pm SEM is indicated. 2 Over $2 \%$ of the total radioactivity added to tubes.

${ }^{3} \chi^{2}$ test with Yates's correction is used. $\chi^{2}=38 \cdot 8$.

ammonium sulphate, binding to Sepharose staphylococcal protein A was measured. On the basis of previous Farr's technique 13 serum samples with high and 11 with low $\beta_{2} \mathrm{~m}$ binding percentages were selected for this assay. A significant difference $\left(\chi^{2} 38.8, P<0.0003\right)$ was observed between these 2 groups of serum, suggesting that IgG was responsible for the $\beta_{2} \mathrm{~m}$ binding (Table 2).

In gel filtration experiments we separated the 3 macromolecular fractions from 3 sera and 3 SFs with high and from 2 sera with low $\beta_{2} \mathrm{~m}$ binding activity. In the 6 positive cases the majority of the binding activity was recovered in the second ' $I g G$ ' peak, while only insignificant binding was found in peaks of negative samples. Fig. 3 shows typical elution patterns from sera of RA patients with high (Fig. 3a) and with low (Fig. 3b) $\beta_{2} \mathrm{~m}$ binding activity. Gel filtration of a synovial fluid with high $\beta_{2} \mathrm{~m}$ binding activity is also shown (Fig. 3c). 


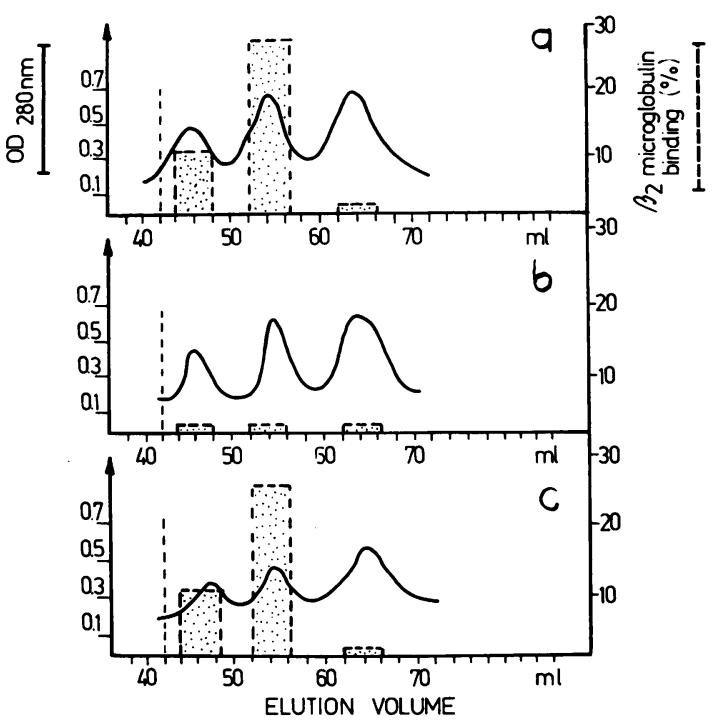

Fig. $3 \quad \beta_{2}$ microglobulin binding by fractions obtained after gel filtration on Sephadex G-200 of 2 sera $(a, b)$ and 1 synovial fuid $(c)$ of $R A$ patients. Void volume is marked by broken line.

\section{Discussion}

The data reported here confirm our previous observations $^{9}$ on the incidence of anti- $\beta_{2} \mathrm{~m}$ autoantibodies in the sera and synovial fluids of RA patients and focus our attention especially on those with different extra-articular manifestations (predominantly pulmonary and nodular). Findings in radioimmune Farr's assay clearly show the prevalence of anti $\beta_{2} \mathrm{~m}$ factors in this subgroup of patients. In sera of patients with SLE a similar frequency of positivity was reported. ${ }^{7}$ We have also investigated serum samples from 30 patients with SLE (unpublished observation) in the same system and found a comparable high mean of binding percentage $(30 \cdot 5 \pm 7 \cdot 0)$ and the same incidence of positive sera $(16 \cdot 6 \%)$.

Furthermore the binding of $\beta_{2} \mathrm{~m}$ by globulins from SFs of RA patients $(22 \cdot 5 \pm 11.5 \%)$ exceeded that of SFs from OA patients $(14 \cdot 1 \pm 9 \cdot 2 \%)$. Interestingly, the absolute levels of the $\beta_{2} \mathrm{~m}$ binding in SFs were relatively low compared to serum. The basis for this difference requires further analysis but high local accumulation of $\beta_{2} \mathrm{~m}^{5}{ }^{17}$ and $\beta_{2} \mathrm{~m}$ containing complexes found in synovial fluid ${ }^{10} 11$ could also be responsible for a lower level of free anti- $\beta_{2} m$ activity.

The binding activity for $\beta_{2} \mathrm{~m}$ in different samples demonstrated in our study is attributed to anti- $\beta_{2} \mathrm{~m}$ antibodies on the following evidence: (1) the ability of Sepharose staphylococcal protein $A$ to bind the IgG fractions with high $\beta_{2} \mathrm{~m}$ binding activity; (2) most of the $\beta_{2} \mathrm{~m}$ binding material was eluted in the IgG peak after chromatography on Sephadex G-200 gel.

Poor attachment of $\mathrm{IgG}_{3}$ and other immunoglobulin classes to SprA allows the possibility that other immunoglobulin molecules also contribute to the total binding activity found in sera and SFs. The presence of nonantibody components among the $\beta_{2} \mathrm{~m}$ binding molecules has also been proposed.18 19 The participation of soluble HLA chains in the binding of $\beta_{2} \mathrm{~m}$ is less probable, as we failed to detect significant binding reactivity in the third peak of Sephadex G-200 gel filtration, the region corresponding to the molecular weight of the free HLA chains.

The nature of the binding activity found in the first macromolecular peak needs further clarification, since $\beta_{2} \mathrm{~m}$-IgG complexes in antibody excess and with free binding sites for $\beta_{2} \mathrm{~m}$ may be also present in this fraction. ${ }^{11}$

The binding percentages even in human serum samples with relatively high $\beta_{2} \mathrm{~m}$ binding activity were low compared to that of standard rabbit anti- $\beta_{2} \mathrm{~m} \mathrm{IgG}$. The binding capacity of $0.1-0.01 \mu \mathrm{g}$ of the heterologous antibody is equivalent to the $1: 4$ dilutions of the human serum and SF samples. It is attractive to speculate that we measure only a part of the autoantibody response, as autoantibodies with higher avidity are probably rapidly removed by surface $\beta_{2} \mathrm{~m}$ of different cells. As an alternative interpretation, a difference between the serological specificity of heterologous antibodies produced against purified urinary $\beta_{2} \mathrm{~m}$ and naturally occurring autoantibodies to $\beta_{2} \mathrm{~m}$ can be suspected. The stimulus for the formation of $\beta_{2}$ m-specific autoantibodies is still unknown. $\beta_{2} \mathrm{~m}$ shed from cells or in immune complexes, virus-modified surface $\beta_{2} \mathrm{~m}, \beta_{2} \mathrm{~m}$ microaggregates, or altered configuration of cytophylic $\beta_{2}$ m reassociated to the cell membranes might all be autoantigenic.

The immunopathological significance of these autoantibodies in SLE has been convincingly shown by their lymphocytotoxic properties in this disease. ${ }^{8}$ Heterologous antibodies directed to human $\beta_{2} \mathrm{~m}$ have been reported to interfere with different forms of cellular immune response in vitro. ${ }^{2021}$ Moreover anti- $\beta_{2} \mathrm{~m}$ heteroantibodies can evoke a dissociation of HLA- $\beta_{2} \mathrm{~m}$ complex in the cellular membrane, causing a loss of the alloantigeneic configuration of the HLA chains. ${ }^{22}$

Autoantibodies might also interfere with different cell functions and provoke the formation of ICs of $\beta_{2} \mathrm{~m}$ specificity. 
Analysing the reactivity of anti- $\beta_{2} \mathrm{~m}$ autoantibodies may help to elucidate the immunopathological features of RA and especially its extra-articular manifestations.

We thank Dr L. Hodinka and Dr Z. Balogh for valuable discussion and Mrs R. Hajdu and Miss K. Árvay for their excellent technical assistance.

This work was supported by a grant (No. 6-07-0304-01-2/ M) from the Scientific Research Council, Ministry of Health, Hungary.

\section{References}

1 Evrin P E, Wibbel L. The serum levels and urinary excretion of $\beta_{2}$ microglobulin in apparently healthy subjects. Scand J Clin Lab Invest 1972; 29: 69-74.

2 Shuster J, Gold P, Poulik M D. $\beta_{2}$-microglobulin levels in cancerous and other disease states. Clin Chim Acta 1976; 67: 307-13.

3 Ericson D, Bratthall D, Bjöck L, Myhre E, Kornvall G. Interactions between human serum proteins and oral streptococci reveal occurrence of receptors for aggregated $\beta_{2}$ microglobulin. Infect Immun 1979; 25: 279-83.

4 Weissel M, Scherak O, Fritzsche H, Kolarz G. Serum $\beta_{2}$ microglobulin and SLE. Arthritis Rheum 1976;19: 968.

5 Manicourt D, Brauman H, Orloff S. Plasma and urinary levels of $\beta_{2}$ microglobulin in rheumatoid arthritis. $A n n$ Rheum Dis 1978; 37: 328-32.

- Talal N, Grey H M, Zvaifler N, Michalsky J P, Daniels $T$ E. Elevated salivary and synovial fluid $\beta_{2}$ microglobulin in Sjögren's syndrome and rheumatoid arthritis. Science 1975; 187: 1196-8.

7 Ooi B S, Ooi Y M, Pesce A J, Pollak V E. Antibodies to $\beta_{2}$ microglobulin in the sera of patients with systemic Jupus erythematosus. Immunology 1977; 33: 535-41.

8 Revillard J P, Vincent C, Rivera S. Anti- $\beta_{2}$ microglobulin lymphocytotoxic autoantibodies in systemic lupus erythematosus. J Immunol 1979; 122: 614-8.

- Falus A, Merétey K, Böhm U, Bozsóky S. Rheumatoid factors bind $\beta_{2}$ microglobulin; detection of $\beta_{2}$ microglobulin-complexes in rheumatoid arthritis. Arch Immunol Therap 1979; 27 : 647-54.

10 Male D, Roitt I M, Hay F C. Analysis of immune complexes in synovial effusions of patients with rheumatoid arthritis. Clin Exp Immunol 1980; 39: 297-306.

11 Falus A, Merétey K, Glikmann G, et al. $\beta_{2}$ microglobulin containing IgG complexes in sera and synovial fluids of rheumatoid arthritis and systemic lupus erythematosus patients. Submitted to Scand J Immunol 1980.

12 Peterson P A, Rask L, Limblon B. Highly purified papain solubilized HL-A antigens contain beta-2 microglobulin. Proc Natl Acad Sci USA 1974; 71: 35-8.

13 Merétey K, Böhm U, Falus A, Bozsóky S. Radioimmune double PEG precipitation technique for detecting complexed IgE. J Immunol Methods 1979; 26: 233-8.

14 Creighton W D, Lambert P H, Miescher P A. Detection of antibodies and soluble antigen-antibody complexes by precipitation with polyethylene glycol. J Immunol 1973; 111: 1219-26.

15 Lowry O H, Rosenbrough N J, Farr L, Randall R J. Protein measurement with the folin phenol reagent. $J$ Biol Chem 1951 ; 193: 265-75.

16 Cathcart E S, O'Sullivan T M. Standardization of the sheep cell agglutination test. The use of pooled reference sera and haemagglutination trays. Arthritis Rheum 1968; 8: $530-7$.

17 Falus A, Merétey K, Böhm U, Bozsóky S. High synovial fluid/serum ratio of beta-2-microglobulin and simultaneous occurrence of hidden rheumatoid factors in RA Rev Int Rhumatol 1979; 43: 287-96.

18 Natori T, Hansen T. Component fragments obtained by acidic dissociation of the alpha-glycoprotein associated with beta-2-microglobulin in mouse plasma. Transplantation 1977 ; 23: 191-4.

19 Seon B K, Pressman D. A spontaneously occurring complex of $\beta_{2}$ microglobulin and a fragment of $\gamma$-chain of IgG: isolation from the urine of a patient with plasma cell leukemia and characterization. J Immunol 1977; 118: 1962-5.

20 McCalmon R T, Kubo R T, Grey H M. Inhibition by anti- $\beta_{2}$ microglobulin antisera of responder cells and not of stimulator cells in mixed lymphocyte reaction. Scand J Immunol 1975 ; 4: 613-6.

21 Ringden O, Möller E. B-cell mitogenic effects on human lymphocytes of rabbit anti-human $\beta_{2}$ microglobulin. Scand J Immunol 1975; 4: 171-9.

22 Lancet D, Parham P, Strominger J L. Heavy chain of HLA-A and HLA-B antigens in conformationally labile: a possible role for $\beta_{2}$ microglobulin. Proc Natl Acad Sci USA 1979; 76: 3844-8. 